Preprints are preliminary reports that have not undergone peer review. They should not be considered conclusive, used to inform clinical practice, or referenced by the media as validated information.

\title{
Placenta in SARS-CoV-2 infection: a new target for inflammatory and thrombotic events
}

\section{Luca Bertero}

Pathology Unit, Department of Medical Sciences, University of Turin, Turin, Italy

Fulvio Borella

Obstetrics and Gynecology 1U, Department of Surgical Sciences, Sant'Anna Hospital, University of Turin, Turin, Italy

Giovanni Botta

Pathology Unit, “Città della Salute e della Scienza di Torino” University Hospital, Turin, Italy

\section{Andrea Carosso}

Obstetrics and Gynecology 1U, Department of Surgical Sciences, Sant'Anna Hospital, University of Turin, Turin, Italy

\section{Stefano Cosma}

Obstetrics and Gynecology 1U, Department of Surgical Sciences, Sant'Anna Hospital, University of Turin, Turin, Italy

\section{Marialuisa Bovetti}

Obstetrics and Gynecology 1U, Department of Surgical Sciences, Sant'Anna Hospital, University of Turin, Turin, Italy

\section{Marco Carosso}

Obstetrics and Gynecology 1U, Department of Surgical Sciences, Sant'Anna Hospital, University of Turin, Turin, Italy

\section{Giancarlo Abbona}

Pathology Unit, "Città della Salute e della Scienza di Torino" University Hospital, Turin, Italy

\section{Mauro Papotti}

Pathology Unit, Department of Oncology, University of Turin, Turin, Italy

\section{Paola Cassoni ( $\sim$ paola.cassoni@unito.it)}

Pathology Unit, Department of Medical Sciences, University of Turin, Turin, Italy

\section{Chiara Benedetto}

Obstetrics and Gynecology 1U, Department of Surgical Sciences, Sant'Anna Hospital, University of Turin, Turin, Italy

\section{Research Article}

Keywords: COVID-19, SARS-CoV-2, pathology, thrombosis, inflammation, obstetrics, gynecology, placenta, preterm

Posted Date: May 21st, 2020

DOI: https://doi.org/10.21203/rs.3.rs-30412/v1

License: (c) (i) This work is licensed under a Creative Commons Attribution 4.0 International License. Read Full License 


\begin{abstract}
Infection by SARS-CoV-2 has been shown to involve a wide range of organs and tissues, leading to a kaleidoscope of clinical conditions. Within this spectrum, an increased rate of preterm deliveries has been reported in women with COVID-19. High expression of proteins (ACE2/TMPRSS2) required for SARS- CoV-2 cell entry has been observed in the maternal-fetal tissues, supporting the possibility of placental viral involvement. A consecutive series of 6 placentas, delivered by 5 women with COVID19 have been investigated. Three out of six placentas showed changes consistent with chronic villitis, while in one case chronic histiocytic intervillositis was diagnosed. Vascular abnormalities consisting of thrombo- hemorrhagic alterations were identified in the three cases with chronic villitis. These pathological findings: i) provide a basis to explain the higher rate of obstetric complications in these patients; 2) suggest the need to investigate heparin use in COVID-19 affected pregnant patients to prevent adverse outcomes.
\end{abstract}

\title{
Background
}

On March 12, 2020, due do the rapid escalation of the coronavirus disease 2019 (COVID-19) outbreak, the WHO declares a pandemic. 1 COVID-19 is caused by the severe acute respiratory syndrome coronavirus 2 (SARS-CoV-2), a betacoronavirus similar to SARS-COV and MERS-CoV, with multiple possible transmission routes and characterized by a high infectivity.2, 3 Emerging data on maternal outcomes of COVID-19 suggest that clinical course is similar to non-pregnant patients4, 5, 6 and outcomes of perinatal COVID-19 infection are reassuring.7 However, adverse effects on newborns, such as fetal and respiratory distress, thrombocytopenia accompanied by abnormal liver function and even death have been reported.8 In addition, evidence of an higher incidence of preterm birth is being increasingly reported.9, 10 Concern is also rising on the possibility that SARSCoV-2 may be vertically transmitted,11, 12, 13 but most patient series do not report cases of proved vertical transmission.9, 10, 14

To date, reported data regarding placental histopathology in COVID-19 are extremely limited (four cases in total),15, 16 but high expression of proteins (ACE2/TMPRSS2) required for SARS-CoV-2 cell entry has been observed in maternal-fetal interface tissues enabling the possibility of placental viral involvement.17 Moreover, the increased thrombotic risk and the inflammatory activation described in patients with COVID-1918, 19, 20 make the placenta a potential target of pathophysiological phenomena which could affect pregnancy outcomes and support the preliminary evidence of increased preterm birth risk.

For all these reasons, histological analysis of placentas delivered by women with COVID-19 could add insightful information. The aim of this work was to evaluate the consecutive series of placentas delivered at our Institution from women with COVID19 infection, investigating the occurrence of pathological changes and the potential correlations with obstetric outcomes.

\section{Case Series}

\section{Case 1 - Pathological findings}

Placenta weight was 590 grams before formalin fixation, lateral dimensions were $16 \mathrm{~cm} \times 15 \mathrm{~cm}$ with thickness ranging from 2 $\mathrm{cm}$ to $3 \mathrm{~cm}$. Umbilical cord length was $45 \mathrm{~cm}$, its structure normal and a peripheral insertion was observed. Placental macroscopic features were normal with translucent membranes. Histological examination showed only mild abnormalities including a scant lymphocytic inflammation which involved both the decidua and basal placental villi with initial villous agglutination (Figure 2A-2B). Lymphocytes showed a prevalent T cell cytotoxic (CD8-positive) phenotype (Figure 2C-2D). These findings were consistent with chronic villitis (low grade, multifocal since inflammatory foci were present on more than one slide). 21 Focal intervillous hemorrhage was also identified, while maturation was normal with features suggesting initial hypermaturation.

\section{Case 2 - Pathological findings}


Placenta weighted 429 grams before fixation, dimensions were $15.5 \mathrm{~cm} \times 15 \mathrm{~cm} \times 2$ to $3.1 \mathrm{~cm}$ thickness. Umbilical cord (length: $16 \mathrm{~cm}$ ) and membranes showed a normal morphology. After sectioning, focal and small whitish areas were observed close to the chorial surface and multiple, small (largest dimension $<1 \mathrm{~cm}$ ) hemorrhagic areas were also identified. Microscopically, this case showed areas of intervillous thrombosis, hemorrhage and fibrin laminar deposition (Figure 3A) as well as microvascular thrombosis with intimal proliferations (Figure 3B). Significant foci of lymphocytic inflammation (CD8-positive) were present, involving the decidua and multiple villi (Figure 3C-3D), consistent with chronic villitis (low grade, multifocal). 21 Villous maturation was consistent with the gestational age.

\section{Case 3 - Pathological findings}

Placenta weight was 460 grams prior to formalin fixation, dimensions: $14 \mathrm{~cm} \times 14 \mathrm{~cm} \times 2$ to $3 \mathrm{~cm}$ thickness. Umbilical cord morphology was normal and insertion central, length: $28 \mathrm{~cm}$. Membranes were translucent. Sectioning showed focal whitish areas (largest dimension: $8 \mathrm{~mm}$ ). Histological features included foci of villous/intervillous lymphocytic inflammation involving both the maternal and the fetal side as well the decidua in which this infiltrate was associated with signs of thrombohemorrhagic vasculopathy and partial trophoblast loss (Figure 4A-4B). Prevalence of CD8-positive cells was observed (Figure 4C). Similarly to the previous cases, these findings were consistent with a chronic villitis (low grade, multifocal). 21 Villous infarction areas were also present (Figure 4D) as well as avascular villi consistent with fetal thrombotic vasculopathy. Villous maturation was within normal range with just focal chorangiosis.

\section{Case 4 - Pathological findings}

The first placenta weighted 410 grams after formalin fixation, dimensions were $16 \mathrm{~cm} \times 14 \mathrm{~cm}$ with a thickness ranging 1 to 3 $\mathrm{cm}$. Umbilical cord length was $16 \mathrm{~cm}$ with a normal morphology and central insertion. Membranes presented a greenish discoloration and had a normal insertion. Sectioning showed extensive hemorrhagic subchorial areas consistent with partial placental abruption (Figure 5A). Histological examination confirmed the presence of hemorrhagic areas located below the fetal surface (Figure 5B), associated with chronic hypoxia signs (intervillous necrotic areas with focal calcifications) (Figure 5C). Accelerated villous maturation was also focally present. Decidual morphology was normal.

The second placenta weight was 235 grams after fixation and dimensions were $14 \mathrm{~cm} \mathrm{x} 15 \mathrm{~cm}$ with thickness ranging between 0.5 and $2.5 \mathrm{~cm}$. Umbilical cord insertion was paracentral, and length was $20 \mathrm{~cm}$. Membranes showed a greenish discoloration similarly to the first placenta. Microscopically, features consistent with accelerated villous maturation were noted. No other abnormalities were present.

\section{Case 5 - Pathological findings}

Placenta weight was 370 grams after fixation, dimensions: $15 \mathrm{~cm} \times 12 \mathrm{~cm}$ with a thickness ranging between 1 to $3.2 \mathrm{~cm}$. Umbilical cord length was $18 \mathrm{~cm}$ with a paracentral insertion. Membranes appearance was normal. After sectioning, focal abruption was observed (Figure 6A). Histological examination showed intervillous histiocytic infiltration (CD68-positive) with perivillous fibrin deposition (Figure 6B-6C), a finding consistent with chronic histiocytic intervillositis. Areas showing villous conglutination, loss of trophoblasts and focal microcalcifications were also observed (Figure 6D). Focal features of accelerated villous maturation were also present.

\section{Discussion}

In this manuscript, we report the pathological findings observed in six consecutive placentas delivered from five women affected by COVID-19. Differently from the limited data reported so far, 15 we describe for the first time pathological abnormalities potentially related to SARS-CoV-2 infection which could help understand the incoming reports suggesting higher rates of obstetric complications in these patients. 
In 4 cases, we found microscopic signs of inflammation involving the decidua and the chorial villi: three out of four cases showed a CD8-positive T cell lymphocytic infiltrate, while in the remaining case an intervillous histiocytic infiltrate was identified.

The presence of an inflammatory lymphocytic infiltrate (cytotoxic CD8+ T cell lymphocytes in particular, as observed in our series) and of villous damage are consistent with the diagnosis of chronic villitis.22, 23 Of note, none of these three patients had comorbidities that could justify the presence of placental inflammation. Chronic villitis etiology is often related to an undergoing infection, although in most cases it is not possible to identify the specific etiopathogenetic agent: these cases are defined as "villitis of unknown etiology" (VUE) and can be found in 2-33.8\% of placentas.24 Within the group of chronic villitis secondary to maternal infections, viruses are the most frequently involved pathogens and many specific agents, such as varicella zoster, herpes simplex virus, cytomegalovirus, and influenza A/H1N1, have been found to be associated with this condition.25, 26, 27, 28 Little is known about the association between placental pathology and coronavirus infections. Seven placentas from coronavirus-infected women during the 2002-2004 SARS outbreak have been previously described:29 histological examination found no abnormalities in $2 / 7$, an increase in subchorionic and intervillous fibrin in $3 / 7$, and massive thrombotic vasculopathy associated with intra-uterine growth restriction (IUGR) in the remaining 2/7 cases. No signs of chronic villitis were detected in any case and the same is true for MERS infections.30 Based on present knowledge, infection by SARSCoV-2 is characterized by an extensive immune response with activation of both CD4+ and CD $8+$ lymphocytes $18,31,32$, thus findings consistent with chronic villitis could be expected in the presence of placental involvement, also considering the high expression of ACE2 in decidual cells, villous cytotrophoblast and syncytiotrophoblast cells.17

Moreover, experiences derived from influenza A/H1N1 infections in pregnancy suggest that activation of cellular immune response with release of inflammatory cytokines can lead to indirect placental damage.28 Considering this evidence, the placenta could be potentially harmed because of intrinsic active virus replication and/or through indirect activity of inflammatory cytokines.33 Viral in situ assessment (by immunohistochemistry for viral proteins and/or in situ hybridization of viral RNA) will be important to define which specific mechanisms are involved in this setting.

In the fourth case with inflammatory abnormalities, features consistent with chronic histiocytic intervillositis were identified. This rare entity is usually associated with maternal immunologic conditions like systemic lupus erythematosus, lupus anticoagulant and antiphospholipid syndrome.34, 35 Despite the different type of inflammatory infiltrate (histiocytic versus lymphocytic) and of etiologies (chronic histiocytic intervillositis is usually not related to viral infections), chronic histiocytic villositis is frequently associated with chronic villitis (30\% to $50 \%$ of cases), supporting a potential overlap in terms of involved immunologic pathways.36, 37 Moreover, alveolar histiocytic infiltration seems to be a frequent autoptic hallmark of SARS-CoV2 infection.38 Lastly, it has to be noted that this patient's significant comorbidities (chronic hypertension, severe obesity, and gestational diabetes) are not usually associated with chronic histiocytic intervillositis.

Our data open up an interesting perspective: the three patients with chronic villitis had a shorter/milder history of COVID-19 ( $<14$ days, estimated time for IgG appearance in patients serum)39, while chronic histiocytic intervillositis was found in a patient with long-standing and more severe symptoms (Figure 1). Could placental alterations mirror the stage of immune response to SARS-CoV-2 and/or infection severity? Should this prove to be true, placenta could be used as a representative tissue to investigate SARS-CoV-2 pathogenetic mechanisms helping avoid the biases of autoptic samples. Perspective and integrated studies (i.e. including seriated viral and serological testing) on larger series are needed to characterize these clinico- pathological correlations and address this hypothesis.

Vascular alterations represent the second type of abnormalities observed in our series. Thrombo- hemorrhagic alterations were mainly found in association with chronic villitis (Cases 1, 2 and 3): in these samples, thrombi involving the arterial microcirculation ( $<1 \mathrm{~mm}$ in diameter) were present in association with an inflammatory infiltrate, similarly to the alterations observed in the lungs of patients who died of COVID-19.38 The relationship between COVID-19 and systemic coagulopathy with a thrombo- inflammatory state has been well documented40, 41 and placental thromboses were also described in two cases of SARS-CoV during the previous outbreak as previously listed. In Case 4 of our series, an extensive hemorrhagic placental abruption was observed, but this finding is probably unrelated to SARS-CoV-2 infection. 
Regarding our knowledge about the clinical outcomes of pregnancy in COVID-19 patients, it is based on limited series and systematic reviews. Chen et al. 6 reported the outcomes of a relatively large series of pregnant women affected by COVID-19 observing a high rate $(14 / 68,21 \%)$ of preterm delivery. A systematic review evaluating 41 pregnancies affected by COVID-19 confirmed this observation, reporting preterm birth ( $<37$ weeks) in above $40 \%$ of pregnancies. 9

Could the poorer obstetrics outcomes reported in women with COVID-19 be related to SARS-CoV-2- induced inflammatory and/or vascular abnormalities? The findings of our study provide an initial pathological basis for these clinical findings: chronic villitis/VUE as well as vascular abnormalities are associated with several obstetric and neonatal adverse outcomes including preterm birth.22, 23, 27, 42, 43, 44 Moreover, it is well known that an inflammatory/infectious reaction can lead to preterm delivery by increasing prostaglandins secretion or by impairing the fetal immune tolerance.

Negative results of SARS-CoV-2 placental swabs observed in our series should not be taken as a conclusive evidence of SARSCoV-2 absence in these tissues. This finding could rather depend on compartmentalization of virus replication within specific cell types. This hypothesis is supported by the differential expression of ACE2 and TMPRSS2, proteins required for SARS-CoV-2 cell entry, observed in the maternal-fetal interface tissues.17, 45 This open question could also be efficaciously addressed by in situ viral assays which will hopefully become more widely available in the coming weeks.

The main limitation of our observations is that our pathological findings are shared by multiple conditions and etiologies, which could have been pre-existent at time of SARS-CoV-2 infection. Nevertheless, some considerations support this relationship: i) the observed rate of abnormalities is higher compared to what could have been expected in a consecutive unselected series of placentas; ii) findings are consistent with other viral infections and with our current knowledge about SARS-CoV-2 pathogenetic mechanisms; iii) patients' histories did not include comorbidities justifying the identified pathological hallmarks. Analysis of larger series of cases and in situ viral assays will be needed to definitively prove and characterize the causative role of SARSCoV-2. Nevertheless, our findings are important to shed a light on the reported associations between COVID-19 infection and poorer obstetrics outcomes.

Finally, can therapeutic implications be derived from our data? As prophylactic low-molecular-weight heparin is recommended in pregnant women with high thrombotic risk,46, 47 our findings provide a pathological basis to consider heparin use in COVID-19 affected pregnant patients to prevent inflammatory and vascular thrombotic complications. This suggestion is in line with the recent proposal of The Society of Thrombosis and Haemostasis which recommends (if not otherwise contraindicated) the use of prophylactic low molecular weight heparin in all patients who require hospitalization for COVID-19, regardless of illness severity.48

\section{Materials And Methods}

Our study is based on the pathological analysis of 6 consecutive placentas delivered from 5 women affected by COVID -19 admitted to the Obstetrics and Gynecology clinic of S. Anna Hospital-"Città della Salute e delle Scienza di Torino", University of Turin from March 22, 2020 to April 23, 2020. Sample collection was performed within the framework of the "SARS-CoV-2 infection during pregnancy and puerperium: an Italian Obstetric Surveillance System (ItOSS)" study by the Italian National Institute of Health. All patients showed symptomatic COVID-19 disease confirmed by a nasopharyngeal swab according to World Health Organization (WHO) guidelines. SARS-CoV-2 RNA was detected using an automated real-time RT-PCR assay [DiaSorin Molecular Simplexa ${ }^{\mathrm{TM}}$ COVID-19 Direct, target genes S and ORF1ab]. Pathological examination was performed according to routine procedures and immunohistochemistry was set up on a BenchMark ULTRA platform (Ventana Medical Systems Inc., Tucson, AZ, USA). The study was conducted in accordance with The Code of Ethics of the World Medical Association (Declaration of Helsinki and following amendments) for studies involving humans and within the guidelines and regulations defined by the Research Ethics Committee of the University of Turin. Patients signed a written informed consent. Data supporting study results are included within the manuscript.

\section{Declarations}




\section{Conflicts of Interest}

The authors declare they have no conflict of interest.

\section{Acknowledgements}

The present study was kindly supported by a grant from "Banca del Piemonte" dedicated to COVID-19 research.

\section{Authorship statement}

GB, PC and CB designed the research; all authors contributed to data collection and analysis; $\mathrm{LB}, \mathrm{FB}, \mathrm{GB}, \mathrm{AC}$ and SC drafted the paper; all authors edited the paper and approved the final version.

\section{References}

1. World Health Organization. WHO announces COVID-19 outbreak a pandemic (http://www.euro.who.int/en/healthtopics/health-emergencies/coronavirus-covid-19/news/news/2020/3/who-announces-covid-19-outbreak-a-pandemic).) (2020).

2. Wang W, et al. Detection of SARS-CoV-2 in Different Types of Clinical Specimens. JAMA, (2020).

3. Xiao F, Tang M, Zheng X, Liu Y, Li X, Shan H. Evidence for Gastrointestinal Infection of SARS-CoV-2. Gastroenterology, (2020).

4. Dashraath P, et al. Coronavirus disease 2019 (COVID-19) pandemic and pregnancy. Am J Obstet Gynecol, (2020).

5. Chen $\mathrm{H}$, et al. Clinical characteristics and intrauterine vertical transmission potential of COVID-19 infection in nine pregnant women: a retrospective review of medical records. Lancet 395, 809- 815 (2020).

6. Chen L, et al. Clinical Characteristics of Pregnant Women with Covid-19 in Wuhan, China. N Engl J Med, (2020).

7. Breslin N, et COVID-19 infection among asymptomatic and symptomatic pregnant women: Two weeks of confirmed presentations to an affiliated pair of New York City hospitals. Am J Obstet Gynecol MFM, 100118 (2020).

8. Zhu H, et Clinical analysis of 10 neonates born to mothers with 2019-nCoV pneumonia. Transl Pediatr 9, 51-60 (2020).

9. Di Mascio D, et al. Outcome of Coronavirus spectrum infections (SARS, MERS, COVID 1 -19) during pregnancy: a systematic review and meta-analysis. Am J Obstet Gynecol MFM, 100107 (2020).

10. Yan J, et Coronavirus disease 2019 (COVID-19) in pregnant women: A report based on 116 cases. Am J Obstet Gynecol, (2020).

11. Carosso A, et Pre-labor anorectal swab for SARS-CoV-2 in COVID-19 patients: is it time to think about it? Eur J Obstet Gynecol Reprod Biol, (2020).

12. Alzamora MC, Paredes T, Caceres D, Webb CM, Valdez LM, La Rosa M. Severe COVID-19 during Pregnancy and Possible Vertical Transmission. Am J Perinatol, (2020).

13. Dong L, et Possible Vertical Transmission of SARS-CoV-2 From an Infected Mother to Her Newborn. JAMA, (2020).

14. Della Gatta AN, Rizzo R, Pilu G, Simonazzi COVID19 during pregnancy: a systematic review of reported cases. Am J Obstet Gynecol, (2020). 
15. Chen $S$, et [Pregnant women with new coronavirus infection: a clinical characteristics and placental pathological analysis of three cases]. Zhonghua Bing Li Xue Za Zhi 49, E005 (2020).

16. Baud D, et al. Second-Trimester Miscarriage in a Pregnant Woman With SARS-CoV-2 JAMA, (2020).

17. Li M, Chen L, Zhang J, Xiong C, Li X. The SARS-CoV-2 receptor ACE2 expression of maternal-fetal interface and fetal organs by single-cell transcriptome study. PLoS One 15, e0230295 (2020).

18. Huang C, et Clinical features of patients infected with 2019 novel coronavirus in Wuhan, China. Lancet 395, 497-506 (2020).

19. Tang N, Li D, Wang X, Sun Z. Abnormal coagulation parameters are associated with poor prognosis in patients with novel coronavirus J Thromb Haemost 18, 844-847 (2020).

20. Schett G, Sticherling M, Neurath MF. COVID-19: risk for cytokine targeting in chronic inflammatory diseases? Nat Rev Immunol, (2020).

21. Khong TY, et Sampling and Definitions of Placental Lesions: Amsterdam Placental Workshop Group Consensus Statement. Arch Pathol Lab Med 140, 698-713 (2016).

22. Boog G. Chronic villitis of unknown etiology. Eur J Obstet Gynecol Reprod Biol 136, 9-15 (2008).

23. Kim CJ, Romero R, Chaemsaithong P, Kim Chronic inflammation of the placenta: definition, classification, pathogenesis, and clinical significance. Am J Obstet Gynecol 213, S53-69 (2015).

24. Khong TY, Mooney EE, Nikkels PGJ, Morgan TK, Gordijn Pathology of the placenta : a practical guide. Springer (2019).

25. Altshuler G, Russell The human placental villitides: a review of chronic intrauterine infection. Curr Top Patho/ 60, 64-112 (1975).

26. Becroft DM, Thompson JM, Mitchell Placental villitis of unknown origin: epidemiologic associations. Am J Obstet Gynecol 192, 264-271 (2005).

27. Tamblyn JA, Lissauer DM, Powell R, Cox P, Kilby The immunological basis of villitis of unknown etiology - review. Placenta 34, 846-855 (2013).

28. Meijer WJ, Wensing AM, Bruinse HW, Nikkels PG. High rate of chronic villitis in placentas of pregnancies complicated by influenza A/H1N1 infection. Infect Dis Obstet Gynecol 2014, 768380 (2014).

29. Ng WF, et The placentas of patients with severe acute respiratory syndrome: a pathophysiological evaluation. Pathology $\mathbf{3 8}$, 210-218 (2006).

30. Jeong SY, et al. MERS-CoV Infection in a Pregnant Woman in Korea. J Korean Med Sci 32, 1717- 1720 (2017).

31. Qin C, et al. Dysregulation of immune response in patients with COVID-19 in Wuhan, China. Clin Infect Dis, (2020).

32. Cao X. COVID-19: immunopathology and its implications for therapy. Nat Rev Immunol, (2020).

33. Liu H, Wang LL, Zhao SJ, Kwak-Kim J, Mor G, Liao AH. Why are pregnant women susceptible to COVID-19? An immunological viewpoint. J Reprod Immuno/ 139, 103122 (2020).

34. Marchaudon V, Devisme L, Petit S, Ansart-Franquet H, Vaast P, Subtil D. Chronic histiocytic intervillositis of unknown etiology: clinical features in a consecutive series of 69 Placenta 32, 140-145 (2011).

35. Mekinian A, et Chronic histiocytic intervillositis: outcome, associated diseases and treatment in a multicenter prospective study. Autoimmunity 48, 40-45 (2015). 
36. Parant O, Capdet J, Kessler S, Aziza J, Berrebi A. Chronic intervillositis of unknown etiology (CIUE): relation between placental lesions and perinatal Eur J Obstet Gynecol Reprod Biol 143, 9-13 (2009).

37. Labarrere CA, Hardin JW, Haas DM, Kassab GS. Chronic villitis of unknown etiology and massive chronic intervillositis have similar immune cell composition. Placenta 36, 681-686 (2015).

38. Carsana L, et Pulmonary post-mortem findings in a large series of COVID-19 cases from Northern Italy. medRxiv, 2020.2004.2019.20054262 (2020).

39. To KK, et al. Temporal profiles of viral load in posterior oropharyngeal saliva samples and serum antibody responses during infection by SARS-CoV-2: an observational cohort Lancet Infect Dis, (2020).

40. Lillicrap D. Disseminated intravascular coagulation in patients with 2019-nCoV pneumonia. J Thromb Haemost 18, 786-787 (2020).

41. Connors JM, Levy JH. Thromboinflammation and the hypercoagulability of COVID-19. J Thromb Haemost, (2020).

42. Redline RW, Patterson Villitis of unknown etiology is associated with major infiltration of fetal tissue by maternal inflammatory cells. Am J Pathol 143, 473-479 (1993).

43. Redline Villitis of unknown etiology: noninfectious chronic villitis in the placenta. Hum Patho/ 38, 1439-1446 (2007).

44. Catov JM, Scifres CM, Caritis SN, Bertolet M, Larkin J, Parks WT. Neonatal outcomes following preterm birth classified according to placental features. Am J Obstet Gynecol 216, 411 e411-411 e414 (2017).

45. Hoffmann M, et SARS-CoV-2 Cell Entry Depends on ACE2 and TMPRSS2 and Is Blocked by a Clinically Proven Protease Inhibitor. Cell 181, 271-280 e278 (2020).

46. Royal College of Obstetricians and Reducing the Risk of Venous Thromboembolism during Pregnancy and the Puerperium.) (2015).

47. ACOG Practice Bulletin No. 196: Thromboembolism in Pregnancy. Obstet Gynecol 132, e1-e17 (2018).

48. Thachil J, et ISTH interim guidance on recognition and management of coagulopathy in COVID-19. J Thromb Haemost n/a.

\section{Tables}

Table 1. Clinical characteristics of the case series 


\begin{tabular}{|c|c|c|c|c|c|c|c|c|c|c|c|c|}
\hline Case & $\begin{array}{l}\text { Age } \\
\text { (years) }\end{array}$ & $\begin{array}{l}\text { Parit } \\
\text { y }\end{array}$ & $\begin{array}{l}\text { Gestati } \\
\text { onal } \\
\text { Age } \\
\text { (weeks) }\end{array}$ & $\begin{array}{l}\text { Comorbidi } \\
\text { ties }\end{array}$ & $\begin{array}{l}\text { COVID-19 } \\
\text { symptoms/ } \\
\text { signs }\end{array}$ & $\begin{array}{l}\text { PRO } \\
\text { M }\end{array}$ & $\begin{array}{l}\text { Delivery } \\
\text { mode }\end{array}$ & $\begin{array}{l}\text { Indication } \\
\text { for C- } \\
\text { section }\end{array}$ & $\begin{array}{l}\text { Weight } \\
\text { (grams } \\
\text { ) }\end{array}$ & $\begin{array}{l}\text { APGA R } \\
\text { scores } \\
\text { at 1' ad } \\
5^{\prime}\end{array}$ & $\begin{array}{l}\text { Placent al } \\
\text { swab }\end{array}$ & $\begin{array}{l}\text { Neonatal } \\
\text { nasopharyngeal } \\
\text { swab }\end{array}$ \\
\hline 1 & 28 & 1001 & 37 & None & $\begin{array}{c}\text { Cough, } \\
\text { fever }\end{array}$ & No & Vaginal & 1 & 3120 & $9 / 9$ & Negativ e & Positive* \\
\hline 2 & 25 & 2002 & 38 & $\begin{array}{c}\beta- \\
\text { thalassemia } \\
\text { trait }\end{array}$ & Fever & No & $\begin{array}{c}\text { C- } \\
\text { section }\end{array}$ & $\begin{array}{c}\text { Two } \\
\text { previous C- } \\
\text { sections }\end{array}$ & 3010 & $9 / 9$ & Negativ e & Negative \\
\hline 3 & 30 & 1001 & 36 & None & Cough & No & Vaginal & I & 2390 & $9 / 9$ & Negativ e & Negative \\
\hline $4 * *$ & 35 & 1001 & 30 & None & $\begin{array}{c}\text { Fever, } \\
\text { rhinorrhea }\end{array}$ & $\begin{array}{c}\text { Yes } \\
(27 \\
\text { weeks } \\
)\end{array}$ & $\begin{array}{c}\text { C- } \\
\text { section }\end{array}$ & $\begin{array}{c}\text { Twin } \\
\text { pregnancy } \\
\text { (dichorioni } \\
\text { c/diamnioti } \\
\text { c), one } \\
\text { previous C- } \\
\text { section } \\
\end{array}$ & $\begin{array}{c}1090 \\
\text { and } 950\end{array}$ & $\begin{array}{l}\text { First } \\
\text { twin: } \\
5 / 9 \\
\text { Second } \\
\text { twin: } 5 \\
\text { / } 9 \\
\end{array}$ & $\begin{array}{l}\text { Negativ e } \\
\text { /Negati } \\
\text { ve }\end{array}$ & $\begin{array}{l}\text { Negative } \\
\text { /Negative }\end{array}$ \\
\hline 5 & 39 & $\begin{array}{c}4003 \\
+2\end{array}$ & 32 & $\begin{array}{c}\text { Chronic } \\
\text { hypertensio } \\
\text { n, severe } \\
\text { obesity } \\
\text { (BMI: 50), } \\
\text { gestational } \\
\text { diabetes, } \\
\text { polyhydram } \\
\text { nios }\end{array}$ & $\begin{array}{c}\text { Rhinorrhea, } \\
\text { cough and } \\
\text { fever since } \\
\text { about one } \\
\text { month. At } \\
\text { admittance: } \\
\text { initial } \\
\text { respiratory } \\
\text { fatigue with } \\
\text { interstitial } \\
\text { pneumonia }\end{array}$ & No & $\begin{array}{c}\text { C- } \\
\text { section }\end{array}$ & $\begin{array}{c}\text { Respiratory } \\
\text { distress, } \\
\text { two } \\
\text { previous C- } \\
\text { sections }\end{array}$ & 2100 & $8 / 9$ & Negative & Negative \\
\hline
\end{tabular}

* In this case a maternal rectal swab was positive for SARS-Cov-2 suggesting a fecal contamination of the newborn during the vaginal labor

**SARS-CoV-2 infection was found at 27 weeks of gestational age

BMI: Body Mass Index, C-section: cesarean section, IUGR: intrauterine growth restriction, PROM: prelabor rupture of membranes

Table 2. Pathological findings of the case series 


\begin{tabular}{|c|c|c|}
\hline Case & Age & Pathological findings \\
\hline 1 & $\begin{array}{l}28 \\
\text { years }\end{array}$ & $\begin{array}{l}\text { - Weight: } 590 \text { grams (before fixation). } \\
\text { - Dimensions: } 16 \mathrm{~cm} \text { X } 15 \mathrm{~cm} \text { X } 2 \mathrm{~cm} \text { to } 3 \mathrm{~cm} \text { thickness. } \\
\text { - Translucent membranes. } \\
\text { - Umbilical cord: } 45 \mathrm{~cm} \text {. Normal morphology and insertion. } \\
\text { - Sectioning: no abnormalities. } \\
\text { - Scant lymphocytic inflammation (CD8-postive), mainly located within the decidua and the basal half, } \\
\text { - Focal intervillous hemorrhage. } \\
\text { - Normal villous maturation with just focal signs of hypermaturation. }\end{array}$ \\
\hline 2 & $\begin{array}{l}25 \\
\text { years }\end{array}$ & $\begin{array}{l}\text { - Weight: } 429 \text { grams (before fixation). } \\
\text { - Dimensions: } 15.5 \mathrm{~cm} \text { X } 15 \mathrm{~cm} \text { X } 2 \mathrm{~cm} \text { to } 3.1 \mathrm{~cm} \text { thickness. } \\
\text { - Translucent membranes. } \\
\text { - Umbilical cord: } 16 \mathrm{~cm} \text {. Normal morphology. } \\
\text { - Sectioning: focal whitish areas close to the chorial surface and small (<1 cm) hemorrhagic foci. } \\
\text { - Significant foci of lymphocytic inflammation (CD8-positive) involving the decidua and multiple villi, } \\
\text { consistent with chronic villitis (low grade, multifocal). } \\
\text { thrombosing intervillous thrombosis, hemorrhage and fibrin laminar deposition as well as microvascular } \\
\text { - Normal villous maturation. }\end{array}$ \\
\hline 3 & $\begin{array}{l}30 \\
\text { years }\end{array}$ & $\begin{array}{l}\text { - Weight: } 370 \text { grams (before fixation). } \\
\text { - Dimensions: } 15 \mathrm{~cm} \text { X } 112 \mathrm{~cm} \text { X } 1 \mathrm{~cm} \text { to } 3 \mathrm{~cm} \text { thickness. } \\
\text { - Translucent membranes. } \\
\text { - Sectioning: focal whitish areas (up to } 8 \mathrm{~mm} \text { ). } \\
\text { - Villous /intervillous lymphocytic (CD8-positive) inflammation involving the decidua and both the placental } \\
\text { maternal and fetal halves, consistent with chronic villitis (low grade, multifocal). } \\
\text { - Decidua: thrombotic-hemorrhagic vasculopathy. } \\
\text { - Areas of villous infarction with trophoblastic loss and focal thrombi. } \\
\text { - Focal presence of avascular villi with fetal thrombotic vasculopathy. } \\
\text { - Normal villous maturation with just focal chorangiosis. }\end{array}$ \\
\hline $\begin{array}{c}4 \\
\text { First } \\
\text { placenta }\end{array}$ & $\begin{array}{l}35 \\
\text { years }\end{array}$ & $\begin{array}{l}\text { - Weight: } 410 \text { grams (after fixation). } \\
\text { - Dimensions: } 16 \mathrm{~cm} \text { X } 14 \mathrm{~cm} \text { X } 1 \mathrm{~cm} \text { to } 3 \mathrm{~cm} \text { thickness. } \\
\text { - Greenish discoloration of membranes. } \\
\text { - Umbilical cord: } 16 \mathrm{~cm} \text {. Normal morphology and insertion. } \\
\text { - Histological features consistent with partial placental abruption. }\end{array}$ \\
\hline
\end{tabular}




\begin{tabular}{|c|c|c|}
\hline & & $\begin{array}{l}\text { - Hemorrhagic areas below the fetal surface, associated with chronic hypoxia signs (intervillous necrotic } \\
\text { areas with focal calcifications). } \\
\text { - Focal features consistent with accelerated maturation. }\end{array}$ \\
\hline $\begin{array}{c} \\
\text { Second } \\
\text { placenta }\end{array}$ & & $\begin{array}{l}\text { - Weight: } 235 \text { grams (after fixation). } \\
\text { - Dimensions: } 14 \mathrm{~cm} \text { X } 15 \mathrm{~cm} \text { X } 0.5 \mathrm{~cm} \text { to } 2.5 \mathrm{~cm} \text { thickness. } \\
\text { - Greenish discoloration of membranes. } \\
\text { - Umbilical cord: } 20 \mathrm{~cm} \text {. Normal morphology and paracentral insertion. } \\
\text { - Features consistent with accelerated maturation. }\end{array}$ \\
\hline 5 & $\begin{array}{l}39 \\
\text { years }\end{array}$ & $\begin{array}{l}\text { - Weight: } 370 \text { grams (after fixation). } \\
\text { - Dimensions: } 15 \mathrm{~cm} \text { X } 12 \mathrm{~cm} \text { X } 1 \mathrm{~cm} \text { to } 3.2 \mathrm{~cm} \text { thickness. } \\
\text { - Translucent membranes. } \\
\text { - Umbilical cord: } 18 \mathrm{~cm} \text {. Normal morphology and paracentral insertion. } \\
\text { - Sectioning: focal placental abruption. } \\
\text { - Intervillous histiocytic infiltration (CD68-positive) with perivillous fibrin deposition. } \\
\text { - Focal accelerated villous maturation. }\end{array}$ \\
\hline
\end{tabular}

\section{Figures}

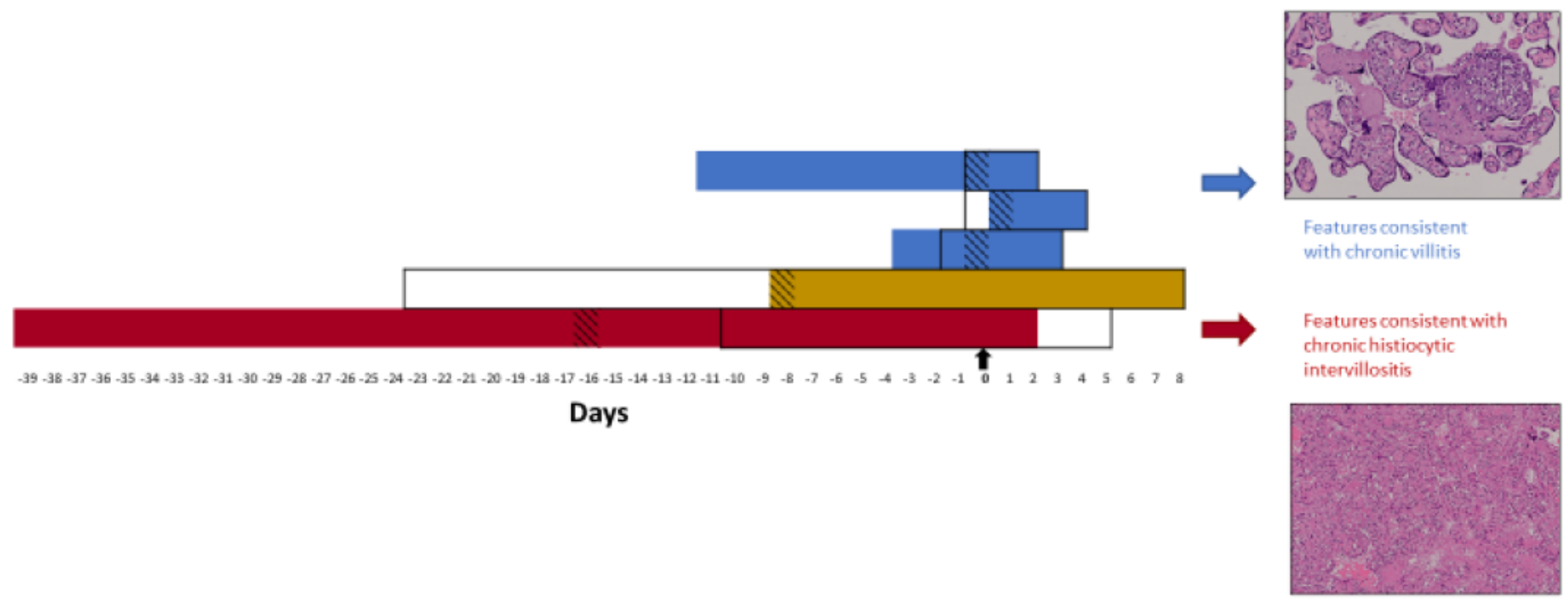

\section{Figure 1}

Outline of COVID-19 clinical course and placental pathological findings. Findings consistent with chronic villitis were found in patients with shorter COVID-19 duration and milder symptoms (blue), while chronic histiocytic intervillositis was diagnosed in Case 5 after long-standing and more severe symptoms (red). Patient 4 showed extensive placental abruption (yellow). Black arrow (Day 0): delivery time. Black rectangles: hospitalization. Colored boxes: days with COVID-19 symptoms. Striped boxes: time of nasopharyngeal swab. 


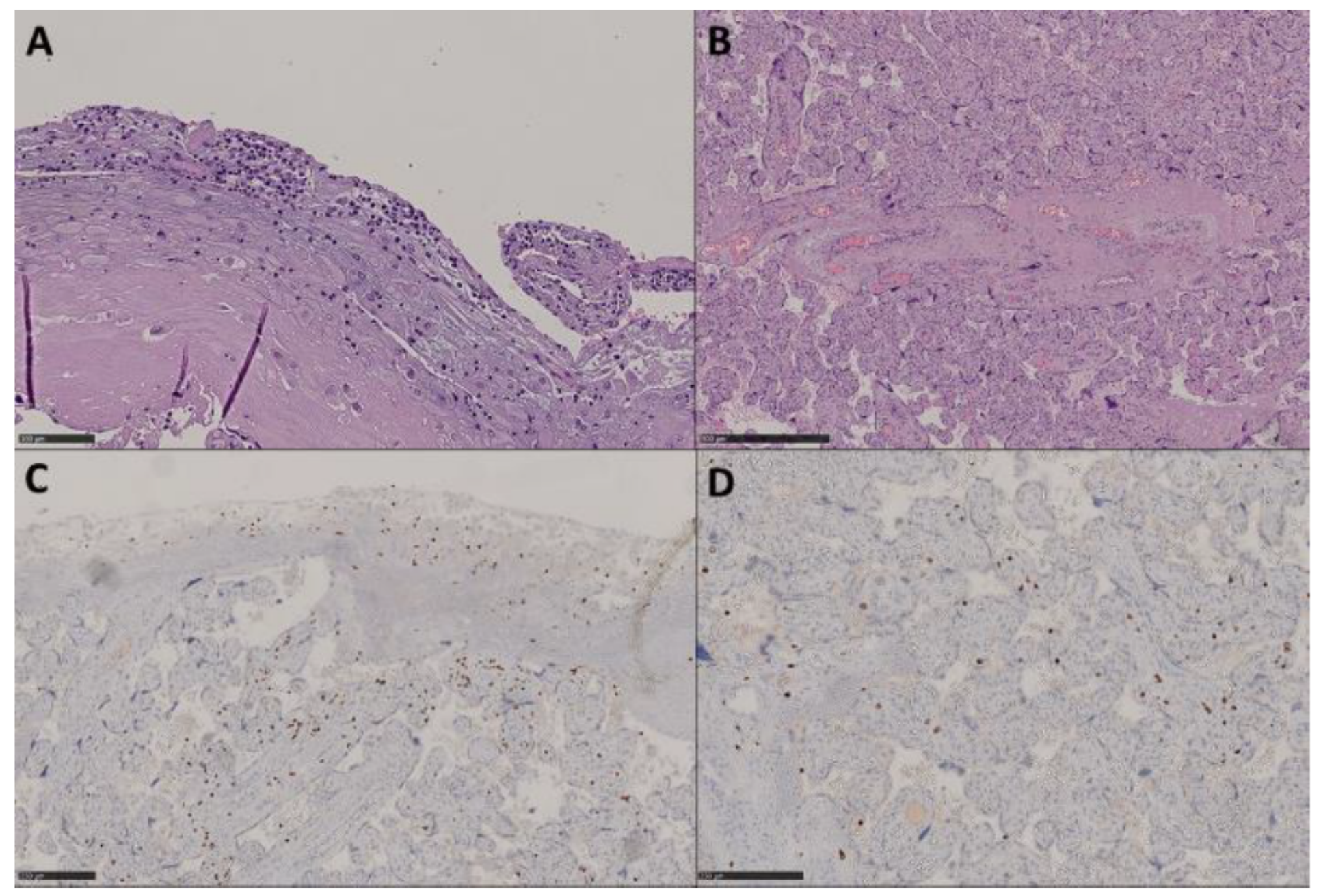

\section{Figure 2}

Pathological findings of Case 1. Mild decidual (A: HE, 200X) and villous (B: HE, 60X) lymphocytic infiltration was observed with a prevalence of cytotoxic T cells (C: anti-CD8 IHC, 70X; D: anti-CD8 IHC, 100X). These findings were consistent with multifocal, low grade chronic villitis. 


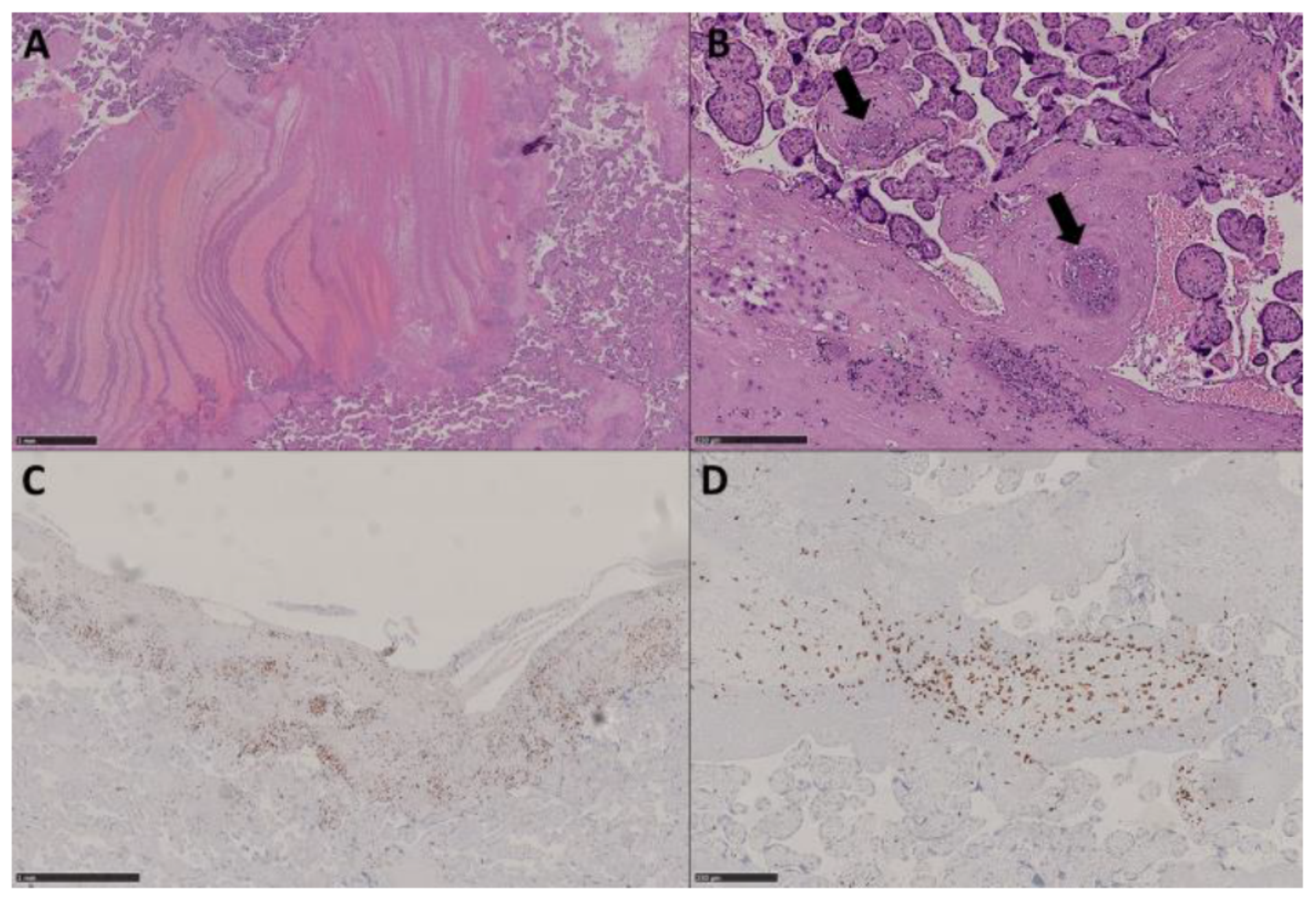

\section{Figure 3}

Pathological findings of Case 2. Thrombo-hemorrhagic areas were present with fibrin laminar deposition (A: HE, 20X) and microvascular thrombosis (arrows) (B: HE, 100X). Significant foci of decidual and villous inflammation were present (C: antiCD8 IHC, 30X; D: anti-CD8 IHC, 80X), consistent with multifocal, low grade chronic villitis. 


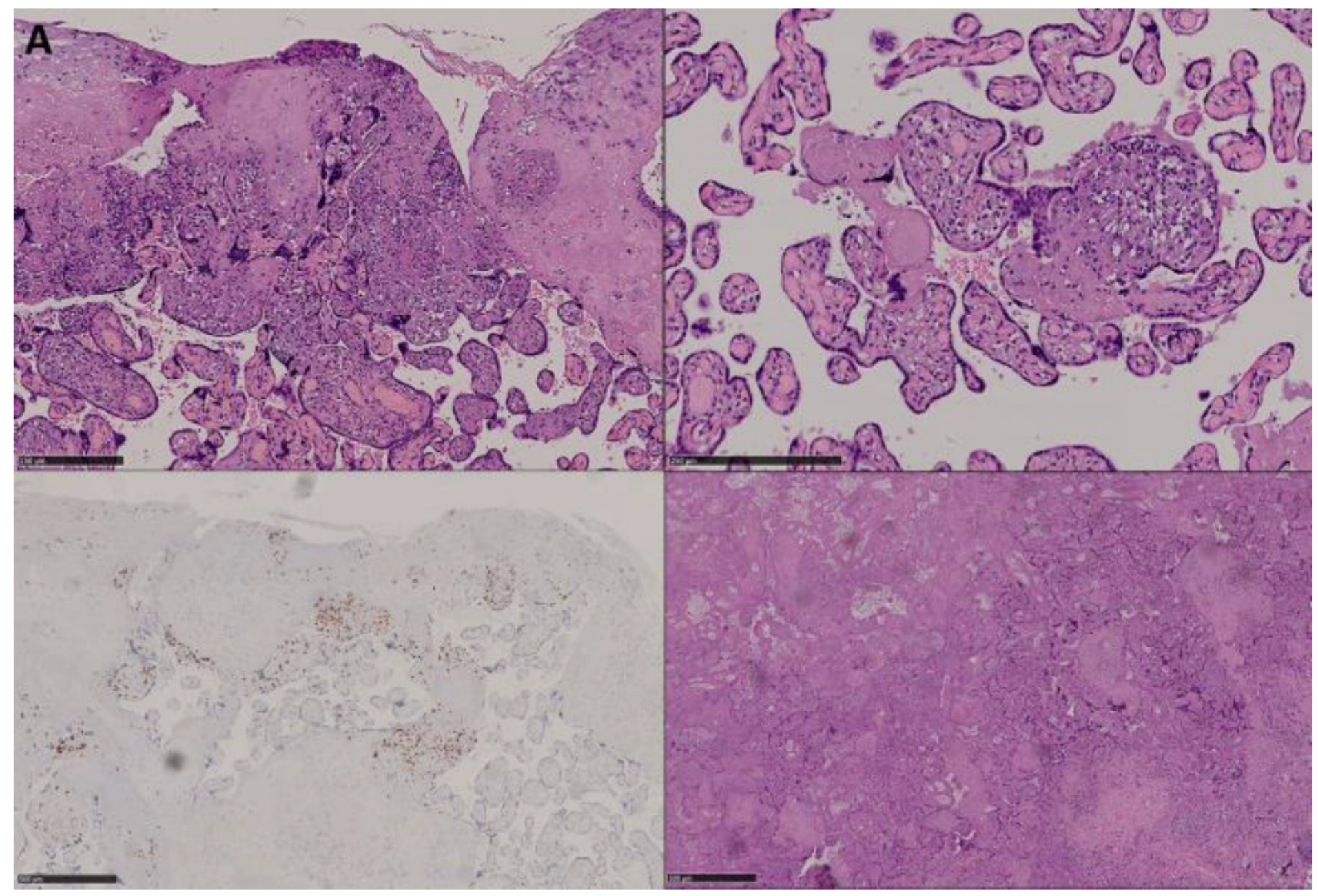

\section{Figure 4}

Pathological findings of Case 3. Similarly to Cases 1 and 2, foci of villous/intervillous lymphocytic infiltration were present in association with thrombo-hemorrhagic vasculopathy and partial trophoblast loss (A: HE, 100X; B: HE, 160X). Prevalence of cytotoxic T cells was observed (C: anti-CD8 IHC, 50X). Villous infarction areas were also present (D: HE, 40X). 


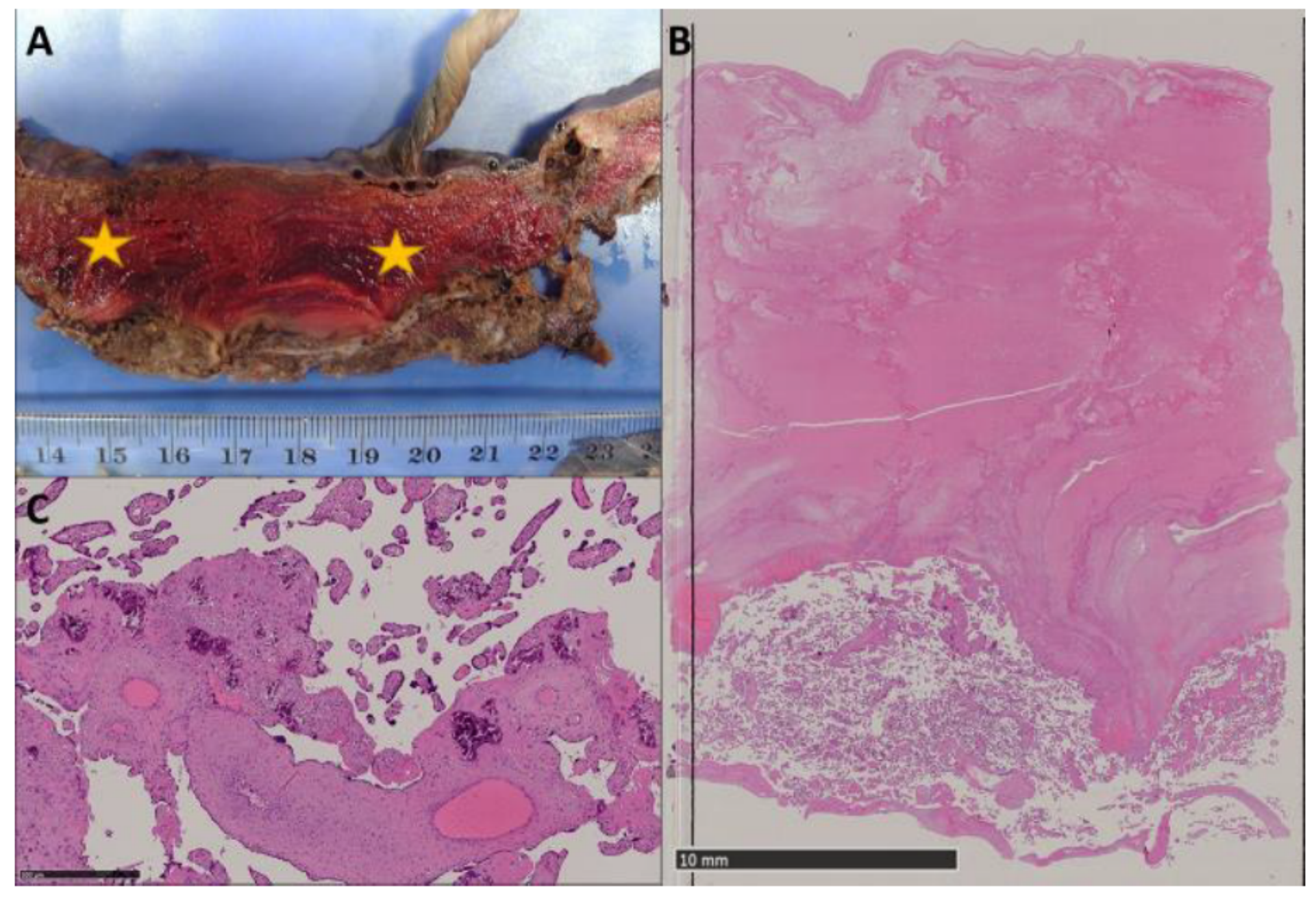

\section{Figure 5}

Pathological findings of Case 4. Extensive subchorial placental abruption was noted during macroscopic examination (stars) (A). Histological examination confirmed the presence of hemorrhagic areas located below the fetal surface (B: HE, 3X), associated with chronic hypoxia signs (C: HE, 60X). 


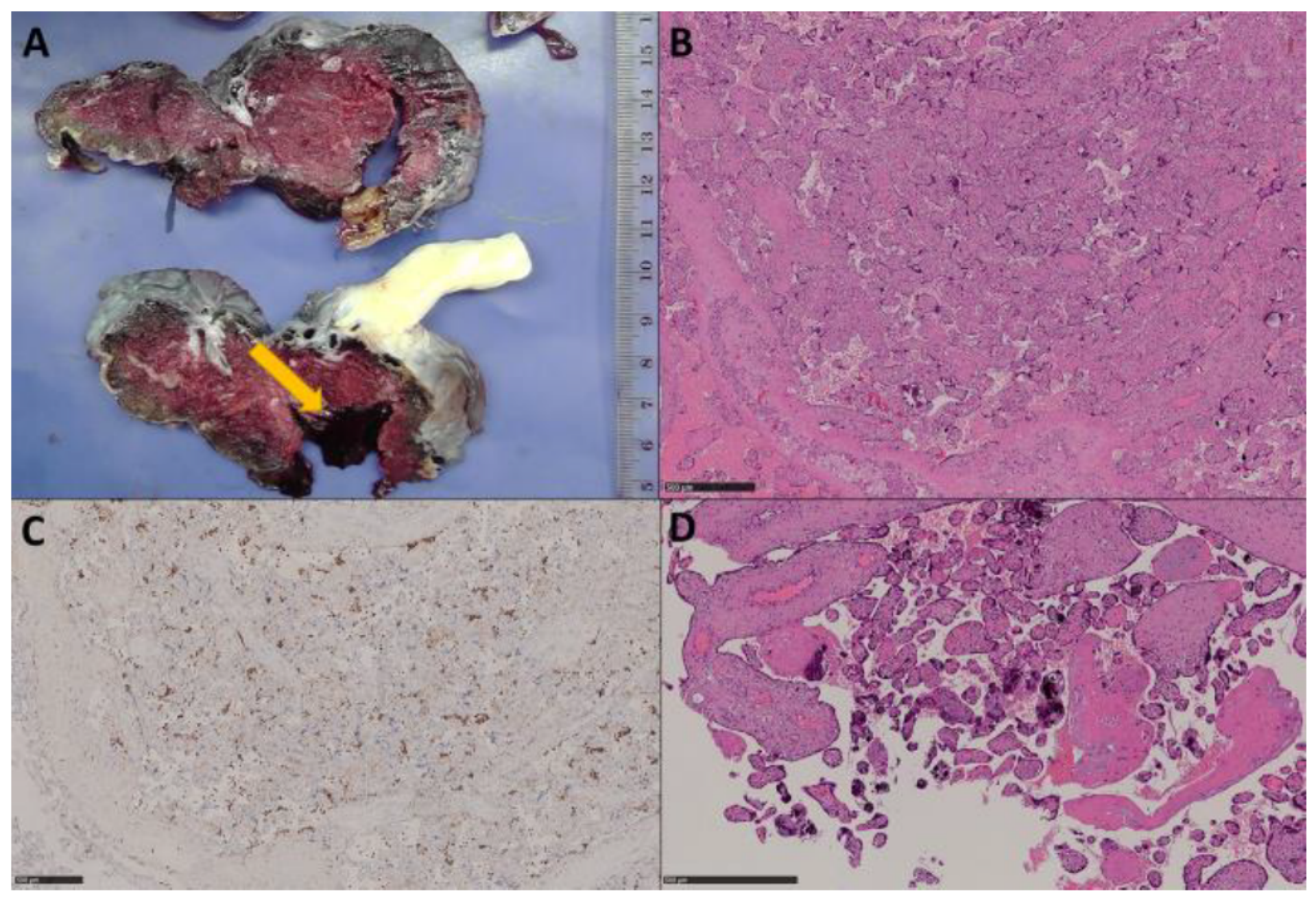

\section{Figure 6}

Pathological findings of Case 5. Focal placental abruption was noted during grossing (arrow) (A). Histiocytic infiltration was present consistently with the diagnosis of chronic histiocytic intervillositis (B: HE, 40X; C: anti-CD68 IHC, 40X). Villous conglutination with loss of trophoblasts and microcalcification was also observed (D: HE, 70X). 